
Kemampuan Membaca Al-Qur'an Siswa di SDIT Bintang Tangerang Selatan

\author{
Dean Hermawan ${ }^{1}$, Roup ${ }^{2}$, Acep Jurjani ${ }^{3}$ \\ ${ }^{1}$ STAI Fatahillah Serpong -Kp. Campaka Ds. Lebak Jaya, Kec. Karangpawitan, \\ Garut. Email: deankibo1@gmail.com. \\ ${ }^{2}$ STAI Fatahillah Serpong - Kp. Jaha Ds. Malangnengah, Kec. Pagedangan, \\ Tangerang. E-mail: roupdc@gmail.com. \\ ${ }^{3}$ STAI Fatahillah Serpong -Jl. Raya Cisauk-Lapan Cibadak Kel. Suradita, Kec. \\ Cisauk, Tangerang. E-mail: acepjurjani@gmail.com.
}

\begin{abstract}
One of the important problems faced by Al-Qur'an teachers is overcoming the disorderly students during the teaching and learning process and overcoming the irregularity of the Koran. In order for Al-Qur'an learning activities to run smoothly, many solutions are used, namely methods. In this case the researcher wants to reveal a method of reading the Koran, namely the tilawati method. The purpose of this study was to determine the students 'ability to read the Koran, the application of the tilawati method, supporting and inhibiting factors and to determine the results of students' ability to read the Koran after the implementation of the tilawati method at SDIT Bintang Tangerang Selatan. This research uses qualitative research with a phenomenological approach. This research took place at SDIT Bintang Serpong Utara, South Tangerang. The informants in this study were the principal, teachers, staff and employees of SDIT Bintang. The data collection techniques by interview, observation, documentation and triangulation. The analysis technique used is data presentation, data reduction, and drawing conclusions. This study found that the implementation of Al-Qur'an learning using the tilawati method at SDIT Bintang has gone well in accordance with the tilawati method learning guidelines. The learning outcomes prioritize the improvement in students' reading ability of the Al-Qur'an, with stages namely learning targets, learning process, material and learning evaluation. Then the results of learning Al-Qur'an using the tilawati method are very good so that children get their own pleasure in the learning process and improve much better, this can be seen from the results of the assessment or munaqosyah that have been implemented.
\end{abstract}

Keywords: Tilawati Method, Reading Ability, Al-Qur'an

Abstrak: Salah satu masalah penting yang dihadapi guru Al-Qur'an adalah mengatasi ketidak tertiban santri selama proses belajar mengajar dan mengatasi ketidak lancaran mengaji. Supaya dalam kegiatan belajar Al-Qur'an dapat berjalan dengan lancar, maka banyak sekali solusi yang digunakan yaitu dengan metode. Dalam hal ini peneliti ingin mengungkap sebuah metode membaca Al-Qur'an yaitu metode tilawati. Tujuan dari penelitian ini yaitu untuk mengetahui kemampuan membaca Al-Qur'an siswa, penerapan metode tilawati, faktor pendukung dan penghambat dan mengetahui hasil kemampuan membaca Al-Qur'an siswa setelah diterapkannya metode tilawati di SDIT Bintang Tangerang Selatan. Penelitian ini menggunakan jenis penelitian kualitatif dengan pendekatan fenomenologis. Penelitian ini mengambil lokasi di SDIT Bintang Serpong Utara Tangerang Selatan. Informan dalam penelitian ini adalah kepala sekolah, guru, staf dan karyawan SDIT Bintang. Adapun Teknik pengumpulan data dengan wawancara, observasi, dokumentasi dan triangulasi. Teknik analisis yang digunakan yaitu penyajian data, reduksi data, dan penarikan kesimpulan. Penelitian ini mendapatkan hasil bahwa penerapan pembelajaran Al-Qur'an dengan menggunakan metode tilawati di SDIT Bintang telah berjalan dengan baik sesuai dengan pedoman pembelajaran metode 
tilawati. Hasil pembelajaran mengutamakan pada peningkatan dalam kemampuan membaca Al-Qur'an siswa, dengan tahapan yaitu target pembelajaran, proses pembelajaran, materi dan evaluasi pembelajaran. Kemudian hasil dari pembelajaran Al-Qur'an dengan menggunakan metode tilawati sangat baik sehingga anak mendapat kesenangan tersendiri dalam proses pembelajaran dan meningkat jauh lebih baik, hal tersebut tampak dari hasil penilaian atau munaqosyah yang telah dilaksanakan.

Kata kunci: Metode Tilawati, Kemampuan Membaca, Al-Qur'an 
 \\ PENDAHULUAN}

Dasar-dasar pembentukan dan pengembangan pendidikan Islam yang pertama dan yang paling utama tentu saja adalah Al-Qur'an dan As-sunah. AlQur'an memberikan prinsip yang sangat penting bagi pendidikan dan kehidupan manusia, yaitu penghormatan kepada akal manusia, bimbingan ilmiah, sesuai fitrah manusia serta isi Al-Qur'an sesuai dengan perkembangan zaman yang semakin kompleks. Mengingat pentingnya umat manusia untuk menjadikan Al-Qur'an sebagai pedoman hidupnya, maka mempelajari Al-Qur'an bagi setiap umat Islam merupakan suatu kewajiban dan kebutuhan sebagai pedoman hidup manusia.

Al-Qur'an merupakan kitab suci terakhir yang diturunkan kepada Nabi Muhammad SAW sebagai pedoman dan petunjuk bagi umat Islam untuk mencapai kebahagiaan di dunia dan di akhirat yang mutlak untuk dibaca, direnungkan dan di amalkan dalam kehidupan sehari-hari. Setiap sikap, tindakan, ucapan dan perbuatan seorang muslim haruslah mencerminkan $\mathrm{Al}^{-}$ Qur'an dan tidak boleh bertentangan dengan ajaran-ajaran yang ada didalamnya.

Pengertian Al-Qur'an secara istilahtelah dikemukakan pula oleh para ulama dari berbagai disiplin keahliannya, baik dalam bidang bahasa, Ilmu Kalam, Ushul Fiqih dan sebagainya. Pengertian yang mereka buat antara satu sama lainnya ada sedikit perbedaan. Dalam hal ini tentu bertendensi pada kecenderungan mereka masing-masing.

Syaikh Muhammad ibn Muhammad Abu Syahbah mengemukakan pengertian Al-Qur'an dalam bukunya, (Muhammad ibn Muhammad Abu Syahibah, t.t) sebagai berikut:

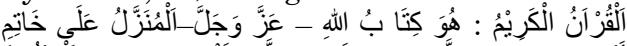

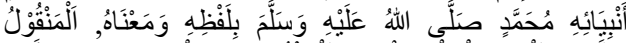



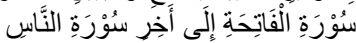

"Al-Qur'an Al-Karim adalah kitab AllahAzza wa Jall-yang diturunkan kepada Nabi terakhir-Nya, Muhammad SAW secara lafal dan maknanya, diriwayatkan secara mutawatir, berfaidah untuk memberi ketetapan dan keyakinan, termaktub dalam mushafmushafyang diawali surat Al-Fatihah dan diakhiri dengan surat An-Nas."

Rasulullah bersabda bahwa sebaikbaik manusia itu adalah orang yang belajar dan mau mengajarkan Al-Qur'an. Jika dikaitkan dengan surat Al-Baqarah ayat 2 yang menyatakan bahwa $\mathrm{Al}-$ Qur'an adalah petunjuk bagi orangorang yang mau bertakwa dan surat Ibrahim ayat 1 yang menyatakan bahwa diturunkannya Al-Qur'an adalah untuk membebaskan manusia dari kegelapan menuju kehidupan yang terang benderang. Diantara tanggung jawab dan kewajiban itu adalah belajar dan mengajarkan

AlQur'an.(Ahmad Syarifuddin: 2004)

Berdasarkan pengertian diatas bahwa Al-Qur'an adalah suatu kegiatan yang yang dilakukan oleh seseorang untuk melafalkan kalam ilahi dengan baik dan benar sesuai dengan ilmu tajwid. Belajar Al-Qur'an itu hendaknya dilakukan semenjak kecil kira-kira umur lima sampai enam tahun, sebab pada umur tujuh tahun Rasulullah telah memerintahkan setiap orang tua agar mulai mendidik anak-anaknya untuk shalat.(Ahmad Syarifuddin: 2004)

Anak tidak ubahnya selembar kertas putih. Apa yang pertama kali ditorehkan di dalam jiwanya, maka itulah yang akan membentuk karakternya. Apabila yang ditanamkan pada jiwa seorang anak adalah tentang agama, keluhuran budi pekerti dan perilaku-perilaku mulia, ajaran-ajaran tersebut akan membentuk semacam zat anti bodi (zat kebal) terhadap pengaruh-pengaruh negatif dari luar dan dari dirinya sendiri. Seperti membenci kekerasan, kesombongan, tidak membangkang terhadap orang tua, rajin belajar dan rajin beribadah dan sebagainya.

Sebaliknya jika yang ditanamkan didalam jiwa seorang anak adalah halhal negatif maka karakter yang membentuk kepribadian anak pun merupakan anti bodi terhadap pengaruh positif, seperti malas belajar, malas beribadah, suka kekerasan, angkuh dan sombong, gila pujian dan sebagainya. 
Dalam proses pembelajaran, kemampuan siswa dalam menguasai materi yang diajarkan merupakan salah satu tujuan yang hendak dicapai. Secara etimologi kemampuan diambil dari kata mampu yang berarti kuasa (bisa, sanggup) melakukan sesuatu (Ramayulis: 2005). Kemampuan juga bisa dikatakan skill yang dimiliki oleh individu untuk melakukan tugas dan pekerjaan. Yang dimaksud kemampuan dalam tulisan ini adalah kesanggupan atau kecakapan yang berkaitan dengan keterampilan membaca Al-Qur'an dengan baik dan benar sesuai dengan ilmu tajwid dan metode yang tepat.

Membaca dalam KBBI berarti melihat serta memahami isi dari apa yang tertulis (dengan melisankan atau hanya dalam hati). Membaca menjadi jantung pendidikan. Ini faktanya, sering kita lupa menganggap pentingnya kegiatan membaca. Kita menganggap penting membaca, namun tidak disertai pelaksanaan kegiatan membaca yang aktif dan kontinu. Semua mata pelajaran di sekolah diberikan berdasarkan buku-buku yang harus dibaca.

Tanpa adanya kegiatan membaca, proses pendidikan dan pembelajaran tak akan berlangsung. Kita dapatkan ilmu pengetahuan atau informasi dari bukubuku. Dengan membaca kita belajar untuk melakukan sesuatu tugas atau pekerjaan kita. Menurut Tarigan "membaca adalah suatu proses yang dilakukan serta digunakan oleh pembaca untuk memperoleh pesan yang disampaikan penulis melalui media bahasa tulis". Sedangkan menurut tampubulon "membaca adalah suatu kegiatan atau cara dalam mengupayakan pembinaan daya nalar" (Darmadi: 2017).

Menurut Nurhadi, "bahwa membaca adalah aktivitas yang komplek yang melibatkan berbagai faktor datangnya dari dalam diri pembaca maupun dari luar" (Darmadi: 2017). Dapat dikatakan bahwa kegiatan membaca merupakan suatu proses untuk memahami suatu bacaan yang dilihat oleh sistem motorik seseorang atau individu. Mmebaca merupakan suatu keterampilan yang sangat kompleks, sewajarnya dalam kegiatan membaca banyak siswa yang kurang menyukainya karena membaca mencakup dan melibatkan serangkaian keterampilan-keterampilan yang lebih kecil.

Dalam bahasa Arab kata membaca diambil dari kata qaraa (Ahmad Warson Munawir: 2001), kata tersebut mempunyai beberapa alternative, makna, antara lain membaca, menelaah/mempelajari, mengumpulkan, melahirkan dan sebagainya. Makna dari qara'a selain berarti membaca teks, juga dimaknai menghimpun. Menurut beliau kata qara'a terambil dari akar kata yang berarti menghimpun, dari kata menghimpun kemudian lahir aneka ragam makna, seperti menyampaikan, menelaah, mendalami, meneliti, mengetahui ciri-ciri sesuatu dan membaca baik tertulis maupun tidak tetulis (M. Quraish Shihab: 1998).

Dijelaskan dalam surat Al-'Alaq 1-5 meninjau lebih dalam pengertian dari membaca (qaraa)

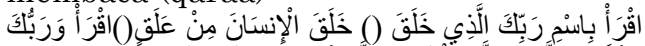

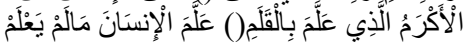

"Bacalah dengan (menyebut) nama Tuhanmu yang Menciptakan (1) Dia telah menciptakan manusia dari segumpal darah (2) Bacalah, dan Tuhanmulah yang Maha pemurah (3) yang mengajar (manusia) dengan perantaran kalam (4) Dia mengajar kepada manusia apa yang tidak diketahuinya (5)". (QS. Al-'Alaq [96 ] : 15)

Surat $\mathrm{Al}-\mathrm{Alaq}$ ayat 1-5 merupakan wahyu pertama yang diterima Nabi Muhammad SAW. Inilah wahyu pertama yang diturunkan oleh Allah SWT kepada Nabi Muhammad SAW, yang dalam kajian Ibnu Katsir dikatakan sebagai rahmat dan nikmat pertama yang dianugerahkan Allah SWT kepada para hamba-Nya. Dan inilah yang menandai penobatan beliau sebagai Rasulullah, utusan Allah SWT, kepada seluruh umat manusia. Wahyu inilah yang menjadi tonggak perubahan peradaban dunia.

Dengan turunnya ayat tersebut maka berubahlah garis sejarah umat manusia. 
Berubah dari kehidupan jahiliyah nan gelap dalam semua aspek, termasuk di dalamnya kegelapan ilmu pengetahuan, menjadi terang benderang. Sejak saat itu, penduduk bumi hidup dalam keharibaan dan pemeliharaan Allah SWT secara langsung. Mereka hidup dengan terus memantau ajaran Allah SWT yang mengatur semua urusan mereka, besar maupun kecil. Dan perubahan-perubahan itu ternyata diawali dengan "Iqra" (bacalah). Perintah membaca di sini tentu harus dimaknai bukan sebatas membaca lembaran-lembaran buku, melainkan juga membaca 'buku' dunia. Seperti membaca tanda-tanda kebesaran Allah SWT. Membaca diri kita, alam semesta dan lain-lain.

Al-Qur'an merupakan nikmat Allah SWT yang sangat besar, yang menjadi pedoman bagi umat Islam. Di dalam AlQur'an terdapat hukum-hukum, perintah dan larangan yang harus di laksanakan oleh umat Islam. Dalam kehidupan sehari-hari sudah sewajarnya bagi orang Islam untuk membaca $\mathrm{Al}^{-}$ Qur'an. Karena dengan membaca AlQur'an kita akan mengetahui petunjuk menuju jalan yang lurus. Allah SWT memberikan kedudukan kepada orang yang mau mempelajari Al-Qur'an pada kedudukan orang terbaik dalam Islam.

Membaca Al-Qur'an tidak boleh sembarangan tetapi harus dengan lancar (fashih) dan benar sesuai dengan kaidah yang telah ditetapkan, karena apabila tidak sesuai dengan kaidah dan aturan yang benar akan berakibat pada kesalahan dalam pemaknaan Al-Qur'an. Kesalahan tersebut dapat merubah makna atau arti dalam ayat Al-Qur'an. Dengan demikian pembelajaran $\mathrm{Al}^{-}$ Qur'an pada anak penting dilakukan agar anak dapat memiliki kemampuan membaca Al-Qur'an dengan baik dan benar sehingga dapat terhindar dari kesalahan ketika membaca.

Keberhasilan sebuah proses pembelajaran tentunya tak lepas dari terpenuhinya serangkaian komponen pembelajaran yang saling berkaitan, salah satu komponen pembelajaran tersebut adalah metode pembelajaran. Metode merupakan cara yang digunakan untuk mengimplementasikan rencana yang telah disusun dalam kegiatan nyata agar kegiatan yang telah disusun tersebut dapat tercapai secara efektif dan optimal.

Salah satu masalah penting yang dihadapi guru Al-Qur'an adalah mengatasi ketidak tertiban santri selama proses belajar mengajar dan mengatasi ketidak lancaran mengaji. Ujung persoalan tersebut berakibat pada mutu bacaan santri yang semakin merosot dan waktu belajarnya semakin lama. Bahkan tidak sedikit santri yang selesai sebelum tartil dan khatam membaca Al-Qur'an. Supaya dalam kegiatan belajar Al-Qur'an dapat berjalan dengan lancar, maka banyak sekali solusi yang digunakan yaitu dengan metode. Metode sebagai suatu cara yang dapat digunakan oleh pendidik dalam menyampaikan materi dengan menggunakan bentuk tertentu.

Metode pembelajaran Al-Qur'an pada hakikatnya adalah mengajarkan AlQur'an pada anak yang merupakan suatu proses pengenalan Al-Qur'an tahap pertama dengan tujuan agar anak mengenal huruf sebagai tanda suara atau tanda bunyi. Sekarang ini masih banyak metode membaca Al-Qur'an yang cenderung konvesional (kesepakatan), yaitu dengan nada lurus sehingga terkesan menoton yang berdampak pada pembelajaran yang kurang dapat diminati oleh peserta didik sehingga berdampak pada hasil belajar peserta didik. Selain harus mengenal hurufhuruf hijaiyah tentu saja dibutuhkan keterampilan membaca Al-Qur'an dengan perlahan-lahan dan tidak terburu-buru dengan bacaan baik benar sesuai dengan makhraj dan sifatsifatnya sebagaimana dijelaskan dalam ilmu tajwid (Abdul Majid Khon: 2008). Dari kata tartil inilah yang lahir istilah murotal yaitu membaca Al-Qur'an secara baik, benar dan lancar dengan irama standar rost.

Seiring berkembangnya zaman maka banyak metode-metode yang diciptakan untuk menunjang keberhasilan peserta didik dalam membaca Al-Qur'an dengan ciri-ciri tertentu demi mencapai keberhasilan dalam pembelajaran. 
Metode apapun yang berkembang, masing-masing mempunyai kelebihan dan kelemahan. Banyak sekali jenis tekhnik, metode dalam pembelajaran $\mathrm{Al}^{-}$ Qur'an mulai dari cara klasik hingga modern.

Metode secara harfiah menggambarkan jalan atau cara suatu totalitas yang akan dicapai atau dibangun. Mendekati suatu bidang secara metodis berarti memahami atau memenuhinya sesuai dengan rencana, mengatur berbagai kepingan atau tahapan secara logis dan menghasilkan sebanyak mungkin yang teratur dan berfikir baik untuk mencapai yang dimaksud. Sehingga dapat dipahami bahwa pelajaran agar mencapai tujuan pembelajaran (Ahmad Munjin Nasih: 2009).

Sistem bersangkutan dengan isi ilmu, sementara metode berkaitan dengan aspek formal. Lebih tepat, sistem berarti keseluruhan pengetahuan yang teratur dan totalitas isi dari ilmu. Dalam upayanya mencapai tujuan, pendidikan memerlukan proses maka salah satu prosesnya adalah pengajaran atau pembelajaran dengan kata lain, pembelajaran merupakan metode dalam pendidikan secara umum. Sementara itu pembelajaran itu sendiri memiliki tujuan khusus (Muhammad Ali Bakri: 2017). Jadi dari pemahaman di atas dapat disimpulkan bahwa metode adalah cara, proses atau jalan untuk mencapai suatu tujuan tertentu yang digunakan guru untuk menyampaikan materi pelajaran kepada peserta didik agar tujuan pembelajaran dapat tercapai dengan sebaik-baiknya.

Sedangkan metode tilawati dalam pembelajaran membaca Al-Qur'an yaitu suatu metode atau cara belajar membaca Al-Qur'an dengan ciri khas menggunakan lagu rost dan menggunakan penggunaan yang seimbang antara pembiasaan melalui klasikal dan kebenaran membaca melalui individual dengan teknik baca simak. Metode ini aplikasi pembelajarannya dengan lagu rost. Rost adalah Allegro yaitu gerak ringan dan cepat (M. Sihabul Munir: 1997). Kata Tilawati berasal dari bahasa Arab tilaawatun yang artinya bacaan. Hal ini disimpulkan karena banyaknya kata tilawati yang ditemukan dalam $\mathrm{Al}^{-}$ Qur'an yakni sebanyak 63 buah di dalam ayat $\mathrm{Al}$-Qur'an yang memiliki beragam variasi arti.

Seperti yang terdapat dalam surat Al-Anfaal ayat 31

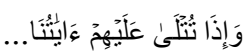

"Dan apabila dibacakan kepada mereka ayat-ayat kami..."

Dalam Kamus Besar Bahasa Indonesia kata tilawati memiliki arti cara membaca ayat Al-Qur'an dengan benar dan indah.

Pengertian metode tilawati menurut Ali Muaffa, merupakan suatu metode belajar membaca Al-Qur'an yang menggunakan strategi pembelajaran dengan pendekatan yang seimbang antara "pembiasaan" melalui sistem klasikal dan "kebenaran membaca" melalui sistem individual dengan teknik "baca simak", dan diharapkan dapat mengurangi bahkan mengatasi permasalahan dalam pembelajaran membaca Al-Qur'an" (Ali Muaffa: 2008).

Pendekatan pembelajaran dengan pembiasaan melalui sistem klasikal pada metode ini sejalan dengan teori behavioristik. Teori belajar behavioristik menjelaskan belajar itu adalah perubahan perilaku yang dapat diamati, diukur dan dinilai secara konkret. Perubahan terjadi melalui rangsangan (stimulans) yang menimbulkan hubungan perilaku reaktif (respon) berdasarkan hukum-hukukm mekanistik. Stimulans tidak lain adalah lingkungan belajar peserta didik, baik yang internal maupun eksternal yang menjadi penyebab belajar. Sedangkan respons adalah akibat atau dampak, berupa reaksi klasik terhadap stimulans. Belajar berarti penguatan ikatan, asosiasi, sifat dan kecenderungan perilaku S-R (stimulusrespons), (Slavi R.E: 2000).

Metode tilawati ini timbul karena keprihatinan para aktivis yang sudah lama berkecimpung di dunia TPQ/TPA, mereka merasasakan masih banyak kalangan umat Islam yang belum bisa membaqca dan menulis Al-Qur'an. Dan beraneka ragam metode pembelajaran 
baca Al-Qur'an yang berkembang sehingga berimbas adanya gap dari masing-masing lembaga penganut beraneka ragam metode tersebut. Selain itu lahirnya metode tilawati ini disebabkan beberapa hal, antara lain: bergesernya peran orang tua terhadap anak (kurang efektif), terhapusnya pelajaran pegon (Arab gundul) di sekolah, perkembangan zaman yang kurang kondusif bagi pendidikan $\mathrm{Al}^{-}$ Qur'an, sebagian guru kehilangan cara efektif untuk mengajar Al-Qur'an sehingga mutu pendidikan kian merosot, penggunaan sebuah metode yang tidak maksimal dan total sehingga berjalan setengah-setengah, fenomena yang terjadi anak biasanya khatam dari sebuah metode pembelajaran Al-Qur'an terlalu lama, keadaan manajemen TPQ/TPA banyak yang semerawut, hanya sekedar mengajarkan Al-Qur'an sebisanya.

Al-Qur'an adalah wahyu Allah yang diturunkan dengan bahasa Arab. Hal yang sedemikian ini, karena nabi yang menerimanya berasal dari bangsa Arab dan berbicara bahasa Arab (Anshori 204). Bahasa ini, sebagaimana bahasabahasa lain, memiliki gramatikal dan cara baca yang khas dan berbeda dari bahasa lainnya. Kaum muslimin yang berasal dari keturunan non Arab tentu mengalami kesulitan dalam membacanya bila mereka tidak mempelajari bahasa Arab ini dengan baik. Karena itu mereka dianjurkan untuk mempelajari bahasa ini agar dapat memahami kitab suci dengan benar. (Anshori: 2014).

Satu hal yang perlu diperhatikan adalah bahwa cara membaca Al-Qur'an itu tidak sama dengan membaca bukubuku yang berbahasa Arab. Maksudnya adalah ada aturan-aturan khusus dalam membacanya. Bahkan para ulama sepakat bahwa membaca Al-Qur'an dengan cara khusus yaitu dengan tajwid, hukumnya wajib bagi mereka yang akan membacanya. Kesalahan pada bacaan, baik itu karena tidak diperhatikan panjang atau pendeknya kata, tebal atau tipisnya huruf atau kata, mendengung atau jelasnya kata yang diucapkan, dan lain sebagainya, tentu akan dapat mengubah makna atau maksud yang sesungguhnya.

Adapun konsep tentang kemampuan membaca Al-Qur'an yang ingin diukur oleh peneliti yaitu:

1. Hukum-Hukum Nun Mati dan Tanwin

a. Idzhar Kholqi ( الاظهار الخلق)

Secara bahasa kata idzhar artinya menerangkan atau menjelaskan dan kholqi artinya tenggorokan, yang berarti harus dibaca secara terang, pendek dan jelas apabila nun sukun atau tanwin bertemu dengan salah satu huruf kholqi. Adapun huruf kholqi ada 6 yaitu: hamzah (s), ha'(o), 'ain ( $(\varepsilon)$, ha ( () , ghain $(\dot{\xi})$, kha (خ). Huruf-huruf ini disebut kholqi karena makhroj (tempat keluarnya suara huruf) tersebut adalah kerongkongan. Cara membaca nun mati dan tanwin yang demikian itu harus terang, jelas dan pendek, bunyi suara tetap jelas, tidak samar dan tidak mendengung (Muhammad Alabror: 2011) Contoh مَنْ اَعْطَى , حَانِدِدِإذَا

\section{b. Idhgam}

Idgham menurut bahasa adalah memasukkan sesuatu kepada sesuatu. Sedangkan menurut istilah adalah idgham ialah bertemunya huruf yang bersukun dengan huruf yang berharakat sehingga kedua huruf tersebut menjadi satu huruf dan huruf yang kedua menjadi bertasydid, kemudian lisan mengucapkan huruf tersebut dengan sekali ucapan.

Idgham dalam hukun nun mati dan tanwin dibagi menjadi dua bagian yaitu idgham bigunnah dan idgham bila gunnah" (Wahyudi Moh: 2008). Kedua jenis idghom ini akan dijelaskan sebagai berikut.

\section{1) Idgham bigunnah}

Secara bahasa idgham bigunnah artinya "memasukkan", bigunnah artinya "dengan dengung". Dalam pengertian hukum nun mati dan tanwin, idgham bigunnah ialah apabila nun mati dan tanwin bertemu dengan salah satu huruf idghom yang empat yaitu ya'(ي) nun (ن), mim (२), dan wawu (و), maka dinamakan idgom bigunnah. Keempat huruf idgom bigunnah itu terkumpul dalam lafadz ينمو. 
Cara membaca idgham bigunnah adalah dengan memasukan suara nun mati atau tanwin kepada huruf idgham bigunnah yang ada dihadapannya sehingga menjadi satu ucapan, seakanakan satu huruf. Pada waktu mengidghomkan, suara harus ditasydidkan kepada huruf idgham bigunnah yang ada didepan nun mati atau tanwin, kemudian ditahan kirakira dua ketukan dengan memakai gunnah (dengung) ketika membacanya.

Berbeda dengan hukum lainnya, hukum idgham disini hanya terjadi pada susunan dua kata dan tidak terjadi pada satu kata صنوان, قنوان, بنيان,دنيا

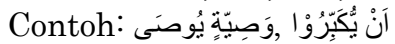

2) Idgham bila gunnah

Bila gunnah artinya tidak memakai gunnah (dengung / sengau). Idgham bila gunnah dalam pengertian hukum nun mati dan tanwin adalah apabila ada nun mati dan tanwin bertemu dengan salah satu lam (J) dan ra'(J) dinamakan idgham bila gunnah.

Cara membaca idgham bila gunnah ialah dengan memasukkan nun mati atau tanwin sepenuhnya kepada huruf lam atau ra tanpa memakai dengung (sengau). Pada waktu mengidghomkan, suara harus di tasydidkan kepada huruf lam dan ra' seraya menahan

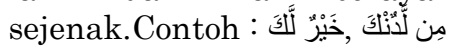

$$
\text { c. Iqlab }
$$

Iqlab menurut bahasa ialah memindahkan sesuatu dari bentuk asalnya (kepada bentuk lain). Sedangkan menurut istilah, iqlab ialah menjadikan suatu huruf kepada makhroj huruf lain dengan tetap menjaga gunnah (sengau pada huruf yang ditukar).

Iqlab dalam pengertian hukum nun mati dan tanwin ialah apabila nun mati atau tanwin bertemu dengan huruf ba ( ب)maka keduanya ditukar dengan huruf mim (२), tetapi hanya dalam bentuk suara, tidak dalam bentuk tulisan.

Cara membaca iqlab adalah dengan mengubah suara nun mati atau tanwin menjadi mim. Kedua bibir dirapatkan untuk mengeluarkan bunyi dengan dibarengi dengung (sengau) yang keluar dari pangkal hidung. Kemudian ditahan sejenak kira-kira dua ketukan sebagai tanda bahwa disana terdapat hukum iqlab. Contoh :

\section{لَيَنْبَدَنَّ لَنَسْفَعًا بِالنَّاصِيَةْ}

Karenanya cara yang terbaik adalah dengan menukar huruf nun mati atau tanwin dengan huruf mim. Disamping karena huruf mim mempunyai sifat yang sama dengan nun, yakni gunnah, juga karena makhroj keduanya sama dengan bae. Sehingga pengucapannya menjadi mudah dan sifat gunnahnya tidak menjadi hilang (Wahyudi Moh: 2008).

\section{d. Ikhfa}

Ikhfa menurut bahasa adalah $A s c^{-}$ Satru(أسََنْرُر)samar atau tertutup. Sedangkan menurut istilah, ikhfa adalah mengucapkan huruf dengan sifat antara idzhar dan idghom, tanpa tasydid dan dengan menjaga gunnah pada huruf yang di ikhfakan.

Ikhfa dalam pengertian hukum nun mati dan tanwin adalah apabila ada nun mati dan tanwin bertemu dengan salah satu huruf ikhfa"e berjumlah lima belas ت ث ز د ذ جس ش ص ض طظ

Cara membaca huruf Ikhfa adalah memadukan antara suara nun mati dan tanwin dengan suara huruf ikhfa yang ada dihadapannya. Suara ikhfa akan terdengan samar, antara idzhar dan idghom, antara suara nun mati dan tanwin masih tetap terdengar namun samar. Demikian juga huruf ikhfa sudah mulai terdengar namun juga samar. Saat proses ikhfa berlangsung, suara ditahan sejenak kira-kira dua ketukan, baru kemudian disambung dengan pengucapan huruf ikhfa (Wahyudi Moh:

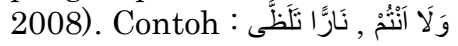

\section{Qolqolah}

Qolqolah menurut bahasa artinya bergerak atau bergetar. Sedang menurut istilah, qolqolah adalah suara tambahan (pantulan) yang kuat dan jelas yang terjadi pada huruf yang mati setelah menekan pada makhroj huruf tersebut (Wahyudi Moh: 2008). Huruf qolqolah ada 5 huruf yaitu Qof (ق) , Tho (b), Ba'(ب), Jim (ج) ,dan Dal(د) atau قطب جد terkumpul dalam kalimat

Qolqolah dibagi menjadi dua, yaitu qolqolah sugro (قلقة صغرى) qolqolah kubro (قلقة كبرى). Adapun penjelan dari kedua jenis qolqolah tersebut adalah sebagai berikut: 
a. Qolqolah Sugro

Sugro artinya kecil. Apabila terdapat salah satu huruf qolqolah yang berharokat sukun/mati (广) dan matinya itu dari asal kata-kata dalam bahasa arab, maka hukumnya disebut qolqolah sugro (Muhammad Al Abror: 2011).

Dalam pengertian lain adalah huruf qolqolah tersebut mati ditengah kalimat, maka dinamakan qolqolah sugro. Contoh

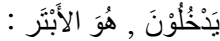

b. Qolqolah Kubro

Kubro artinya besar, maksudnya adalah apabila huruf qolqolah yang lima itu mati atau berharokat sukun $(\dot{\circ})$ dari sebab waqof atau (berhenti) atau titik koma, maka hukum bacaannya disebut qolqolah kubro (Al Abror Muhammad: 2011).

Dalam pengertian lain, apabila huruf qolqolah tersebut dalam keadaan mati diakhir kalimat, maka ia dinamakan

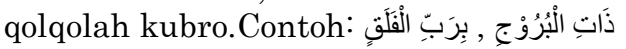

\section{Madd Thobi'i}

Madd Thobi'i disebut juga madd ashli. Secara bahasa madd artinya panjang dan thobi'i artinya biasa. Dalam penjelasan lain, thobi'i artinya tabiat. Dinamakan demikian karena, seseorang yang mempunyai tabiat baik tidak mungkin akan mengurangi atau menambah panjang bacaan dari yang telah ditetapkan. Huruf - huruf mad thobi'i ada tiga, yaitu alif, wau dan ya .

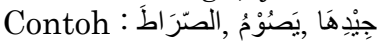

Cara membaca madd thobi'i adalah dengan memanjangkan dua Harakat (1 Alif), baik pada saat Washol maupun pada saat waqof. Membacanya kurang dari satu Alif hukumnya haram syar'i sedang membacanya lebih dari satu Alif sangat makruh (Wahyudi Moh: 2008).

\section{Waqof}

Waqof menurut bahasa ialah alhabsu yang artinya menahan. Sedangkan menurut istilah, waqof ialah memutuskan suara pada suatu kalimat dalam waktu tertentu, tidak begitu lama, kemudian mengambil nafas satu kali dengan niat untuk memulai kembali bacaan Al-Qur'an. (Wahyudi Moh: 2008).

Berdasarkan hasil wawancara peneliti dengan kepala sekolah SDIT Bintang Serpong Utara Tangerang
Selatan, sebelum peneliti terjun secara langsung kelapangan beliau memberikan informasi, bahwa proses pembelajaran Al-Qur'an selama ini berjalan dengan baik sesuai dengan jadwal dan ketentuan yang ditentukan. Namun selama ini kemampuan membaca Al-Qur'an nya masih kurang, masih banyak siswa di SDIT Bintang yang ketika membaca Al-Qur'an terbatabata atau tidak lancar, masih banyak yang tersendat-sendat dalam prakteknya ketika mengucapkan ayat demi ayat Al-Qur'an, kemudian kualitas fashohah dari makhorijul huruf ketika mengucapkan huruf-huruf hijaiyyah masih banyak yang belum sesuai tempat keluarnya huruf dan sifat-sifat huruf yang benar, kemudian masih banyak siswa SDIT Bintang Serpong Utara yang belum mampu mempraktekan hukumhukum tajwid yang dasar dengan baik dan benar.

Dalam konteks pendidikan Al-Qur'an, Sekolah Dasar Islam terpadu (SDIT) sebagai lembaga pendidikan agama Islam dituntut untuk mampu membina peserta didik agar berpedoman pada $\mathrm{Al}-$ Qur'an dalam kehidupan mereka, tugas mulia itu tentu saja tidak ringan mengingat tantangan dan rintangan yang dihadapi semakin berat. Tantangan yang mendesak untuk segera di tangani justru berasal dari para peserta didik sendiri sebab murid-murid yang masuk ke SDIT Bintang tidak semuanya mampu membaca Al-Qur'an dengan baik, bahkan ada yang belum mengenal huruf-huruf Arab sehingga perlu dilakukan perlakuan khusus untuk meningkatkan kemampuan membaca mereka.

Kemampuan dasar membaca $\mathrm{Al}^{-}$ Qur'an harus mereka kuasai sebab selain mempelajari Al-Qur'an mereka juga harus mempelajari bidang studi lain yang mensyaratkan mampu membaca Al-Qur'an, di sekolah SDIT Bintang Serpong Utara Tangerang Selatan kemampuan membaca Al-Qur'an masih rendah, sehingga diperlukan penggunaan metode-metode khusus yang tepat dan akurat agar dapat meningkatkan kemampuan membaca $\mathrm{Al}^{-}$ Qur'an. Di sekolah SDIT Bintang 
Serpong Utara Tangerang Selatan banyak peserta didik yang hanya bisa membaca Al-Qur'an saja tanpa di dasari dengan tajwid, panjang pendeknya, dan asal bunyi saja. Oleh karena itu sangat diperlukan metode tilawati ini dalam mempelajari $\mathrm{Al}$-Qur'an untuk dapat memberikan pengetahuan dan pemahaman dalam membaca Al-Qur'an agar mendapatkan pahala dari Allah SWT.

Berdasarkan latar belakang dan segala bentuk permasalahan dan indikator penelitian yang telah diuraikan di atas, serta mencermati pentingnya kemampuan membaca $\mathrm{Al}^{-}$ Qur'an di SDIT Bintang Serpong Utara Tangerang Selatan serta banyaknya metode yang berkembang saat ini, penulis merasa perlu menentukan salah satu metode yang akan diteliti untuk menghindari kekaburan fokus dalam penelitian ini yaitu metode tilawati. Adapun yang menjadi tujuan dalam penelitian ini yaitu untuk mengetahui kemampuan membaca Al-Qur'an siswa, untuk mengetahuan penerapan metode tilawati, untuk mengetahui faktor pendukung dan penghambat, serta untuk mengetahui hasil kemampuan membaca Al-Qur'an siswa setelah penerapan metode tilawati.

\section{METODE}

Metode penelitian adalah cara yang digunakan untuk mendapatkan data dan informasi serta berbagai hal yang berhubungan dengan masalah yang diteliti, dengan tujuan dan kegunaan tertentu (Sugiyono: 2017). Menurut Mardalis metode diartikan sebagai suatu cara atau teknis yang dilakukan dalam proses penelitian. Sedangkan penelitian itu sendiri sebagai upaya dalam bidang ilmu pengetahuan yang dijadikan untuk memperoleh fakta-fakta dan prinsipprinsip dengan sabar, hati-hati, sistematis untuk mewujudkan kebenaran (Mardalis: 2003).

Jenis penelitian yang digunakan dalam penelitian ini adalah kualitatif dengan menggunakan pendekatan fenomenologis.Sugiyono mengatakan bahwa, penelitian kualitatif adalah penelitian yang menghasilkan data deskriptif berupa data-data tertulis dari orang-orang, fenomena, peristiwa, aktivitas social, sikap, kepercayaan, persepsi dan pemikiran orang secara individual ataupun kelompok (Sugiyono: 2017).

Penelitian kualitatif dengan pendekatan fenomenologis juga memiliki karakteristik yang melekat didalamnya. Menurut Mujib ada dua karakteristik dalam penelitian fenomenologis dalam bidang agama. Pertama, pendekatan ini merupakan metode dalam memahami agama orang lain dalam perspektif netralitas. Dalam situasi ini, peneliti menggunakan prefensi orang yang bersangkutan untuk merekontruksi dalam dan berdasarkan pengalaman orang tersebut. Artinya, dalam kondisi ini peneliti menanggalkan dirinya sendiri (ephoce) dan berupaya membangun dari pengalaman orang lain. Kedua, dalam menggali data pada pendekatan ini dibantu dengan disiplin ilmu yang lain, seperti sejarah, arkeologi, filologi, psikologi, sosiologi, studi sastra bahasa, dan lain-lain (Helaludin Hengki Wijaya: 2019).

Maka dengan kata lain, dalam penelitian kualitatif ini penulis berusaha mencatat, menganalisis dan menginterpretasikan kondisi yang ada. Objek yang penulis teliti adalah efektivitas metode tilawati dalam meningkatan kemampuan membaca $\mathrm{Al}^{-}$ Qur'an siswa. Jenis dari penelitian kali ini adalah menggunakan penelitian lapangan (field reaserch) yaitu dengan mengadakan penelitian dengan cara terjun langsung ke lapangan yang dijadikan sebagai subjek penelitian serta peneliti terlibat langsung didalamnya (J.R Racoo: 2010).

Dalam penelitian ini sumber data yang peneliti gunakan yaitu sumber data primer dan sumber data sekunder adapun data primeradalah data yang diperoleh langsung dari informan, Penentuan informan dalam penelitian kualitatif menyatakan bahwa dapat dilakukan saat peneliti mulai memasuki lapangan selama penelitian berlangsung yaitu memilih orang tertentu yang dipertimbangkan akan memberikan data 
yang diperlukan dan selanjutnya berdasarkan data atau informasi lainnya yang diharapkan dapat memberikan data yang lebih lengkap (Sugiyono: 2017).

Informan dalam penelitian ini adalah kepala sekolah, guru, staf dan karyawan serta siswa SDIT Bintang Serpong utara Tangerang selatan. Adapun teknik pengumpulan data dalam penelitian kualitatif ini dapat dilakukan secara langsung di SDIT Bintang dengan teknik pengumpulan data yang menggunakan teknik observasi (participan observation), Wawancara (interview), dokumentasi dan teknik triangulasi. Dalam observasi ini, peneliti terlibat dengan kegiatan seharihari orang yang sedang diamati atau yang digunakan sebagai sumber data penelitian. Sambil melakukan pengamatan, peneliti ikut melakukan apa yang dikerjakan oleh sumber data, dan ikut merasakan suka dukanya. Dengan observasi partisipan ini, maka data yang diperoleh akan lebih lengkap, tajam, dan sampai mengetahui pada tingkat makna dari setiap perilaku yang nampak (Sugiyono: 2017).

Wawancara adalah suatu teknik pengumpulan data dengan jalan tanya jawab sepihak yang dilakukan dengan sistematik dan berlandaskan pada tujuan penelitian yang ada.Wawancara adalah percakapan dengan maksud tertentu. Percakapan itu dilakukan oleh dua pihak, yaitu pewawancara (interviewer) yang mengajukan pertanyaan dan yang di wawancarai (interview) yang memberikan jawaban atas pertanyaan itu, Maksud mengadakan wawancara, seperti ditegaskan oleh Lincoln dan Guba antara lain: mengkonstruksi mengenai orang, kejadian, kegiatan, organisasi, perasaan, motivasi, tuntutan, kepedulian, dan lain-lain (Lexy J. Moleong: 2001).

Dokumentasi adalah mencari data mengenai hal-hal atau variabel yang berupa catatan, transkip, buku, surat kabar, majalah, parasit, notulen, rapat, agenda, dan sebagainya (Suharsimi Arikunto: 2002). Setelah instrumen dokumentasi dibuat, maka peneliti datang kelokasi penelitian, yakni SDIT Bintang Serpong Utara untuk melakukan pencatatan data dokumentasi yang diperoleh peneliti. Data yang didapatkan selama penelitian yaitu foto dan file berupa gambaran umum sekolah yang berisi visi misi sekolah, struktur organisasi sekolah, serta dokumen-dokumen lain yang ibutuhkan peneliti.

Triangulasi dalam teknik pengumpulan data, triangulasi diartikan sebagai teknik pengumpulan data yang bersifat menggabungkan dari berbagai teknik pengumpulan data dan sumber data yang telah ada. Triangulasi teknik, berarti peneliti menggunakan teknik pengumpulan data yang berbeda-beda untuk mendapatkan data dari sumber yang sama. Peneliti menggunakan observasi partisipatif, wawancara mendalam, dan dokumentasi untuk sumber data yang sama secara serempak. Triangulasi sumber berarti, untuk mendapatkan data dari sumber yang berbeda-beda dengan teknik yang sama (Lexy J. Moleong: 2001).

Penulis melakukan teknik analisis data dengan langkah-langkah sebagai berikut. Pertama, data pendukung dan data utama ditranskripkan. Kemudian, transkrip yang diperoleh hasil wawancara diseleksi dan diserahkan dengan menggunakan kategorisasi dan pengkodian agar mempermudah proses pengklasifikasian. Selanjutnya hasil kategorisasi tadi dideskripsikan, diterjemahkan dan dianalisa dan memperoleh jawaban dari prtanyaan penelitian.

Adapun analisis data dapat dilakukan peneliti yaitu, Data Reduction (Reduksi Data), Data Display (Penyajian Data) dan Conclusion Drawing (Verifikasi Data)

\section{HASIL}

1. Kemampuan membaca Al-Qur'an siswa di SDIT Bintang Serpong Utara Tangerang Selatan

Kemampuan membaca Al-Qur'an yang baik dan benar adalah benar bacaannya, baik dan lancar dalam 
melafadzkannya, tepat dan sesuai dari segi makhraj dan ilmu tajwidnya.

Adapun pertanyaan penulis ajukan kepada guru Ibu Yurike Haryanti (Wakasek Bid. Kurikulum) tentang bagaimana kemampuan membaca AlQur'an siswa. Beliau mengungkapkan:

"Kemampuan membaca pada masing-masing anak berbeda ada siswa yang sebelumnya masuk sekolah udah bisa membaca namun belum mengerti hukumhukum tajwid dan ada juga ada yang belum sama sekali bisa membaca dan mengerti hukumhukum tajwid"

2. Penerapan pembelajaran Al-Qur'an dengan Metode Tilawati di SDIT Bintang

Metode merupakan salah satu komponen penting yang menunjang keberhasilan dari sebuah proses pembelajaran. Penerapan metode dan implementasi yang tidak tepat akan memberikan dampak yang kurang maksimal terhadap hasil dari sebuah proses pembelajaran.

SDIT Bintang merupakan salah satu sekolah yang menerapkan metode tilawati dalam pembelajaran AlQur'annya. Metode tilawati ini merupakan metode pembelajaran $\mathrm{Al}$ Qur'an dengan menggunakan nada-nada dalam tilawah, disampaikan dengan pendekatan klasikal dan baca simak yang diterapkan secara seimbang.

Awal mula berdirinya SDIT Bintang ini menerapkan metode tilawati, kesepakatan untuk menerapkan metode tilawati dengan harapan agar kemampuan siswa dalam membaca $\mathrm{Al}^{-}$ Qur'an dapat lebih baik. Seperti yang diungkapkan oleh Ibu Yurike Haryanti (Wakasek Bid. Kurikulum) sebagai berikut:

"Sejak awal memulai sekolah ini menggunakan tilawati, dengan pertimbangan yang lain kami memilih metode tilawati ini dari hasil musyawarah dengan kepala sekolah beserta Lembaga Tilawati cabang Tangerang Selatan dan berjalan sampai sekarang ini, bahkan sudah di masukan kurikulum khas SDIT Bintang."
Pembelajaran dilaksanakan setiap hari senin sampai jum'at. Proses pembelajaran dimulai dari pukul 07.30 WIB. Setelah itu istirahat dan Sholat Ashar, dan kembali masuk lagi untuk pelajaran tambahan seperti Aqidah Akhlak, Fiqih, dan lain-lainnya. Kemudian pukul 13.30 WIB kegiatan belajar selesai dan pulang. Sebagaimana pernyataan ibu Ibu Yurike Haryanti:

"Kami melaksanakan ini setiap hari dari hari senin sampai jum'at , anak-anak masuk bel pukul o7.30 untuk belajar membaca AlQur'an dengan menggunakan metode tilawati selama 40 menit, kemudian istirahat dan dilanjutkan dengan pelajaran yang lainnya ,ishoma lagi dan pada jam 13.30 kegiatan belajar selesai dan pulang."

Ketertarikan siswa terhadap terhadap kegiatan pembelajaran merupakan suatu hal penting yang harus diperhatikan oleh guru. Penyampaian materi pembelajaran dengan metode yang tepat tentunya akan meningkatkan minat belajar siswa sehingga siswa lebih bersemangat. Penerapan metode tilawati menjadikan minat siswa di SDIT Bintang dan kelas juga lebih kondusif. Pembelajaran yang didukung dengan peraga juga memudahkan guru dalam menyampaikan pelajaran. selain itu siswa Seperti halnya yang diungkapakan oleh ibu Ibu Yurike Haryanti sebagai berikut:

"Pembelajaran dengan menggunakan metode tilawati ini lebih menarik minat para siswa disini karena metode ini menggunakan nada-nada yang dapat membuat anak merasa senang sehingga pembelajaran tidak monoton dan kelas juga lebih kondusif. Dalam pembelajaran menggunakan alat bantu peraga yang menjadikan materi mudah untuk disampaikan, membuat anak juga kadang sampai hafal."

Dari hasil observasi di lapangan penerapan metode tilawati yang ada di SDIT Bintang adalah sebagai berikut: 
a. Target Pembelajaran

Target pembelajaran di dalam penerapan metode tilawati yang ada di SDIT Bintang ini adalah agar anak dapat memiliki kemampuan membaca Al-Qur'an yang baik. Sebagaimana dalam pernyataan ibu Yurike Haryanti:

"Karena target kami dalam pembelajaran Al-Qur'an ini kami ingin meningkatkan dari segi kemampuan dan kualitas dengan cara yang menyenangkan sehingga target perhari 1 halaman, karena ada 44 halaman ,prediksi kami 2 bulan lebih 2 minggu ingsyaallah udah selesai jikalau anak-anak memang cepat. Adapun kalua ada anak yang lambat akan review ulang."

Pembelajaran ditargetkan pada kualitas dan juga target waktu. Target kualitas disini adalah dengan diterapkannya metode tilawati ini diharapkan siswa dapat membaca $\mathrm{Al}^{-}$ Qur'an dengan baik dan benar (tartil), terutama dalam penguasaan tajwid, pemahaman tajwid, fashohah, ghoribul Qur'an, dan suara dan lagu. Sedangkan dalam target waktu berkenaan dengan jenjang tilawati yaitu tilawati dasar (jilid satu sampai jilid lima) dan lanjutan (jilid enam dan Al-Qur'an). Sebagaimana yang diungkapkan oleh ibu Yurike Haryanti:

"Kalau untuk target pembelajaran seperti yang tecantum dalam pedoman pembelajaran tilawati target kami yaitu kualitas dan target waktu. Target kualitas itu jadi siswa diharapkan dapat membaca Al-Qur'an dengan baik, (tartil membaca Al-Qur'an) pemahaman tajwid, fashohah, dan ghoribul Qur'an wamusykilat, dan juga suara dan lagu tilawati. Kalau target waktu berkenaan dengan jenjang tilawati yaitu ada tilawati dasar (yaitu jilid 1 sampai 6) dan lanjutan yaitu untuk yang Al-Qur'an."

b. Proses Pembelajaran

Proses pembelajaran merupakan kegiatan penting dalam penyampain materi dari guru kepada siswa. Sebelum pembelajaran yang perlu dipersiapkan adalah metode tilawatinya itu sendiri, alat peraga, dan ruang belajar.

Dalam proses pembelajaran tilawati menggunakan dua pendekatan, yaitu tekhnik klasikal dengan peraga, dengan penerapan guru membaca santri mendengarkan, guru membaca santri menirukan, dan membaca bersamasama. Kemudian dalam tekhnik baca simak yaitu membaca bergiliran yang satu membaca yang lain menyimak. Sebagaimana penuturan ibu Yurike :

"Kami menggunakan dua pendekatan, yaitu yang pertama klasikal dengan peraga, yaitu guru membaca santri mendengarkan, guru membaca santri menirukan, membaca bersama-sama. Kemudian baca simak yaitu membaca bergiliran yang satu membaca yang lain menyimak."

Pembelajaran dengan klasikal peraga di SDIT Bintang ini menjadikan anak-anak cenderung tidak ramai dan mereka fokus dengan peraga, hal tersebut menjadikan kelas lebih kondusif.

Sedangkan ketika penerapan tekhnik baca simak siswa cenderung kurang konsentrasi karena ia menunggu giliran temannya membaca, sehingga terkadang anak mengantuk ataupun mengobrol dengan temannya. Disisi lain kelebihannya adalah kepercayaan diri siswa dapat meningkat. Sebagaimana yang diungkapkan oleh ibu Yurike Haryanti :

"Sebenarnya pembelajaran klasikal dengan peraga membuat anak itu lebih kondusif, membuat anak tidak rame karena kita membaca secara bareng-bareng. Jadi anak yang rame, yang tidak fokus ataupun ngantuk akan kelihatan. Dan juga anak yang merasa dirinya bisa itu biasannya meninggikan suarannya dan lebih percaya diri. Kelemahannya ketika pembelajaran dengan baca simak anak kurang konsentrasi karena biasanya mereka siap-siap untuk gilirannya, sehingga tidak memerhatikan bacaannya sendiri. Kelebihannya menurut saya ada banyak, membantu pribadi anak 
lebih berkembang secara globalnya, terutama dalam kepercayaan diri siswa karena ketika baca simak dia di dengar teman-temannya."

c. Materi Pembelajaran

Materi yang diajarkan adalah sesuai dengan kurikulum dalam pedoman pembelajaran metode tilawati. Pokok pembelajaran tercantum di halaman awal dalam setiap jilid. Materi pembelajaran ditekankan pada Tajwid, Ghoribul Qur'an, Fasohah dan Makhorijul Huruf. Sebagaimana pernyataan ibu Yurike :

"Materi yang diberikan sesuai dengan kurikulum tilawati, untuk pembelajarannya

kami

menyesuaikan dengan jenjang atau jilid anak itu sendiri. Materi tambahannya yaitu tajwid (terutama panjang pendek atau mad), Makhorijul Huruf, Ghoribul Qur'an, musykilat dan Waqof Ibtida."

d. Evaluasi Pembelajaran

Evaluasi merupakan salah satu cara untuk mengukur kemampuan siswa. Evaluasi atau munaqyosah pembelajaran Al-Qur'an yang ada di SDIT Bintang dilakukan setiap dua bulan sekali dan maksimal tiga bulan. Tujuan munaqosyah adalah untuk mengetahui tingkat kemampuan dan pemahaman para siswa, sehingga dapat diajadikan acuan guru dalam proses kenaikkan jilid. Munaqosyah di SDIT Bintang dilaksanakan secara lisan, yaitu siswa individu membaca materi yang telah ditentukan oleh guru dan guru menilai bacaan siswa. Siswa yang nilainya masih kurang akan diberikan waktu untuk belajar dan melakukan remidi, namun apabila masih belum dapat mencapai target ketuntasan maka akan di review dan mengulangi dijilid sebelumnya dan diprivat oleh guru khusus sebagai penguatan terhadap materi. Sebagaimana yang dijelaskan oleh ibu Yurike Haryanti sebagai berikut:

"Jadi kami disini menekankan evaluasi secara lisan, dan kita laksanakan setiap 2 bulan sekali dan maksimal 3 bulan. Bagi anak yang tidak naik, kami berikan kesempatan untuk remidi serta $d i$ review, dan kami tangani khusus dengan privat sebagai penguatan dan juga memotivasi mereka. Ketika proses evaluasi atau ujian kenaikkan tersebut sebenarnya kita dapat mengukur kemampuan anak dari kebiasannya seharihari."

3. Faktor Pendukung dan Faktor Penghambat dari Penerapan Pembelajaran Al-Qur'an dengan Menggunakan Metode Tilawati di SDIT Bintang

Dalam pelaksanaan sebuah proses pendidikan tentunya tidak lepas dari banyak faktor. Baik itu faktor internal maupun eksternal yang menjadi pendukung maupun penghambat dari berjalannya pelaksanaan pembelajaran.

a. Faktor Pendukung

Faktor pendukung yang menunjang keberhasilan pembelajaran yang ada di SDIT Bintang diantarannya adalah sarana dan prasarana yang memadai. Sarana dan prasarana yang memadai menjadikan pembelajaran lebih mudah disampaikan oleh guru dan diterima oleh siswa.

Sarana dan prasarana yang mendukung penerapan metode tilawati yang ada di SDIT Bintang diantarannya adalah ruang kelas, masjid, peraga, buku-buku tilawati, dan lemari. Sebagaimana pernyataan ibu Yurike sebagai berikut:

"Faktor pendukungnya secara sarana dan prasarana sudah cukup memadai, seperti ruang kelas, musholla, perpustaakan, juga peraga dan bukubuku tilawati sekolah ini sudah memiliki."

Komunikasi yang baik dengan wali murid. Guru dan orang tua siswa disini bekerjasama dalam memantau perkembangan siswa baik itu secara langsung maupun tidak langsung. Secara langsung yaitu orang tua menanyakan langsung keadaan anaknya ke guru, dan dengan tidak langsung yaitu orangtua siswa dan guru menjalin komunikasi melalui group.

Selain dengan para wali murid, komunikasi dan kerjasama yang baik 
antar guru juga menjadi faktor pendukung dalam keberhasilan pembelajaran Al-Qur'an di SDIT Bintang. Diantaranya dalam kegiatan muroja'ah dan diskusi yang dilakukan. Sebagaimana penuturan Ibu Yurike sebagai berikut:

"Untuk dari guru kami
mengadakan muroja'ah
(mengulang) atau belajar bareng
dan berdiskusi yaitu mungkin ada
bacaan tertentu yang belum
dipahami oleh sang guru kita
pecahkan bersama. Agar yang lain
yang belum tahu dapat juga
mengetahuinya dan sekaligus
penerapannya bagaimana. Input
siswa yang sudah memiliki latar
belakang baca tulis Al-Qur'an."

Pengalaman siswa membaca AlQuran menjadi salah satu faktor yang memudahkan para guru dalam menerapkan metode tilawati ini, jadi guru tidak perlu mengenalkan huruf hijaiyah dari dasar kepada siswa.

b. Faktor Penghambat

Faktor penghambat yang ada SDIT Bintang diantaranya adalah cuaca. Keadaan iklim yang kurang mendukung merupakan salah satu faktor eksternal yang dapat menghambat kegiatan pembelajaran. Cuaca hujan dapat memicu anak yang rumahnya jauh menjadi tidak masuk sekolah. Selain itu anak-anak juga senang bermain hujanhujanan sehingga dapat menyebabkan sakit. Seperti yang diungkapkan ibu Yurike :

"Faktor penghambatnya kami melihat diantaranya yaitu ada anak yang izin tidak masuk tentu akan tertinggal dari yang lain jadi terkadang anak ada yang tanpa alasan tidak masuk kelas, kadang ada sakit ataupun karena cuaca yang hujan membuat anak tidak masuk kelas sehingga mereka dapat tertinggal sampai beberapa halaman."

Faktor penghambat selanjutnya dipengaruhi oleh teknis dan kondisi di lapangan, kondisi guru ataupun kondisi siswa. Salah satu faktor yang berkaiatan dalam mempengaruhi kemampuan anak dalam belajar adalah lingkungan keluarga. Terutama orang tua, mereka merupakan sosok yang memiliki peran penting dalam memberikan dukungan dan motivasi terhadap anak. Kurangnya keharmonisan keluarga dan dukungan terhadap anak dapat memicu terhadap rendahnya perekembangan belajar anak. Jadi orang tuaseharusnya dapat memberikan perhatian dan motivasi kepada anaknya sehingga anak merasa bersemangat dan terpacu dalam belajarnya. Pernyataan Ibu Yurike Haryanti sebagai berikut:

"kemampuan anak yang berbeda" beda terkadang anak susah dalam melagukan (bacaan benar tapi nada salah), latar belakang keluarga anak yang berbeda, keluarga sebagai orang yang paling dekat dengan anak jadi paling berpengaruh terhadap perkembangan anak."

4. Hasil dari Penerapan Pembelajaran Al-Qur'an dengan Menggunakan Metode Tilawati di SDIT Bintang

Hasil belajar merupakan puncak dari sebuah proses belajar. Pembelajaran dinyatakan berhasil apabila hasilnya memenuhi tujuan yang telah ditentukan sebelumnya. Dari hasil observasi peneliti pembelajaran Al-Qur'an di SDIT Bintang evaluasi atau munaqosyah pembelajaran tilawati dilakukan dari jilid satu sampai jilid enam. Aspek yang dinilai yaitu Tajwid, Fasohah, suara dan lagu. Pencapaian atau hasil munaqosyah menunjukkan hasil yang bagus. Pencapaian hasil pembelajaran yang bagus tersebut tentunya tak lepas dari minat dan kemampuan siswa yang meningkat daripada sebelumnya. Tidak hanya itu saja tetapi keutungan lain yang didapati adalah kepercayaan diri anak lebih jauh meningkat daripada sebelumnya. Sebagaimana pernyataan ibu Yurike:

"Untuk hasil pembelajaran tilawati disini sejauh ini hasilnya luar biasa. Dari yang sebelumnya panjang pendeknya saja masih berantakan. Kami juga membenahi dari mad, tajwid, waqof ibtida' juga ghorib pelanpelan. Jadi kami membenahi secara ekstra. Menurut saya 
pembelajaran Al-Qur'an dengan metode tilawati ini juga berimbas baik kepada anak secara globalnya, dan kepercayaannya meningkat jauh lebih baik, yang paling high dikalangan anak kelas 5 sudah ada yang menghafal 4 juz, itu dari awal kita didik dari yang belum bisa apa-apa sampai dengan proses menghafal. Adapun anak yang low dikelas 5 sudah bisa membaca Al-Qur'an, dan yang paling low minimal sudah bisa membaca Al-Qur'an meskipun terbata-bata."

Selain itu dengan sedikit waktu kesulitan anak dapat diatasi dan kemampuan anak dapat meningkat. Intinya mereka yang kesulitan dalam belajar awal huruf dengan belajar menggunakan metode tilawati yang bernada ini, dengan sedikit waktu anak cepat bisa Membaca Al-Qur'an.

\section{PEMBAHASAN}

1. Kemampuan membaca Al-Qur'an siswa di SDIT Bintang Serpong Utara Tangerang Selatan

Dalam proses pembelajaran, kemampuan siswa dalam menguasai materi yang diajarkan merupakan salah satu tujuan yang hendak dicapai. Secara etimologi kemampuan diambil dari kata mampu yang berarti kuasa (bisa, sanggup) melakukan sesuatu (Ramayulis: 2005). Kemampuan juga bisa dikatakan skill yang dimiliki oleh individu untuk melakukan tugas dan pekerjaan. Yang dimaksud kemampuan dalam tulisan ini adalah kesanggupan atau kecakapan yang berkaitan dengan keterampilan membaca Al-Qur'an dengan baik dan benar.

Berdasarkan pendapat diatas dapat dipahami bahwa kemampuan adalah kecakapan seseorang dalam melakukan suatu pekerjaan baik di dalam dunia pendidikan maupun diluar dunia pendidikan. Kemampuan membaca $\mathrm{Al}^{-}$ Qur'an yang baik dan benar adalah benar bacaannya, baik dan lancar dalam melafadzkannya, tepat dan sesuai dari segi makhraj dan ilmu tajwidnya.
Berdasarkan wawancara diatas dengan Ibu Yurike Haryanti (Wakasek Bid. Kurikulum) dapat penulis simpulkan bahwa kemampuan membaca Al-Qur'an di SDIT Bintang relatif sedang, ada yang sudah bisa membaca ada juga yang belum bisa membaca $\mathrm{Al}^{-}$ Qur'an.

2. Penerapan pembelajaran Al-Qur'an dengan Metode Tilawati di SDIT Bintang

Metode diartikan sebagai prinsipprinsip yang mendasari kegiatan mengarahkan perkembangan seseorang khususnya dalam proses belajar mengajar, Secara etimologi, metode berasal dari kata method yang berarti suatu cara yang sistematis untuk memudahkan pelaksaan kegiatan dalam mencapai suatu tujuan. Apabila kata kata metode disandingkan dengan kata pembelajaran, maka berarti suatu cara atau sistem yang digunakan dalam pembelajaran yang bertujuan agar anak didik dapat mengetahui, memahami, mempergunakan, menguasai bahan pelajaran tertentu.

Metode tilawati dalam pembelajaran membaca Al-Qur'an yaitu suatu metode atau cara belajar membaca Al-Qur'an dengan ciri khas menggunakan lagu rost dan menggunakan penggunaan yang seimbang antara pembiasaan melalui klasikal dan kebenaran membaca melalui individual dengan teknik baca simak. Metode ini aplikasi pembelajarannya dengan lagu rast. Rast adalah Allegro yaitu gerak ringan dan cepat (M. Misbahul Munir: 1997).

Metode tilawati menurut Ali Muaffa merupakan suatu metode belajar membaca Al-Qur'an yang menggunakan strategi pembelajaran dengan pendekatan yang seimbang antara "pembiasaan" melalui sistem klasikal dan "kebenaran membaca" melalui sistem individual dengan teknik "baca simak", dan diharapkan dapat mengurangi bahkan mengatasi permasalahan dalam pembelajaran membaca Al-Qur'an (Ali Muaffa: 2008).

Metode tilawati ini timbul karena keprihatinan para aktivis yang sudah lama berkecimpung di dunia TPQ/TPA, mereka merasasakan masih banyak 
kalangan umat Islam yang belum bisa membaqca dan menulis Al-Qur'an. Dan beraneka ragam metyode pembelajaran baca Al-Qur'an yang berkembang sehingga berimbas adanya gap dari masing-masing lembaga penganut beraneka ragam metode tersebut. Selain itu lahirnya metode tilawati ini disebabkan beberapa hal, antara lain: bergesernya peran orang tua terhadap anak (kurang efektif), terhapusnya pelajaran pegon (Arab gundul) di sekolah, perkembangan zaman yang kurang kondusif bagi pendidikan $\mathrm{Al}^{-}$ Qur'an, sebagian guru kehilangan cara efektif u8ntuk mengajar Al-Qur'an sehingga mutu pendidikan kian merosot, penggunaan sebuah metode yang tidak maksimal dan total sehingga berjalan setengah-setengah, fenomena yang terjadi anak biasanya khatam dari sebuah metode pembelajaran Al-Qur'an terlalu lama, keadaan manajemen TPQ/TPA banyak yang semerawut, hanya sekedar mengajarkan Al-Qur'an sebisanya.

Abdurrahim Hasan menjelaskan bahwa tilawati dalam pembelajaran membaca Al-Qur'an merupakan suatu metode atau cara belajar membaca $\mathrm{Al}^{-}$ Qur'an dengan ciri khas menggunakan lagu rost dan menggunakan pendekatan yang seimbang antara pembiasaan melalui pendekatan klasikal dan kebenaran membaca dengan pendekatan individual (Abdurrahman Hasan: 2010).

Berdasarkan penjelasan di atas maka dapat diambil kesimpulan bahwa metode tilawati adalah cara membaca Al-Qur'an dengan pendekatan klasikal (membaca, mendengarkan, dan mengikuti) dan pendekatan individual baca simak dengan ciri khas mengguunakan lagu rost dan diajarkan dengan bantuan alat peraga. Diterapkannya metode tilawati sebagai metode dalam pembelajaran membaca Al-Qur'an merupakan salah satu upaya untuk meningkatkan kualitas pendidikan agama Islam. SDIT Bintang Serpong utara Tangerang selatan adalah salah satu dari sekian banyak lembaga pendidikan Islam yang menerapkan metode tilawati dalam pembelajaran membaca Al-Qur'an menggunakan metode tilawati.
Berdasarkan wawancara diatas dengan Ibu Yurike Haryanti S.Ag (Wakasek Bid. Kurikulum) penerapan metode tilawati menjadi keunggulan dalam pembelajaran Al-Qur'an di SDIT Bintang dari mulai didirikannya sekolah sampai saat.

3. Faktor Pendukung dan Faktor Penghambat dari Penerapan Pembelajaran Al-Qur'an dengan Menggunakan Metode Tilawati di SDIT Bintang

Dalam pelaksanaan sebuah proses pendidikan tentunya tidak lepas dari banyak faktor. Baik itu faktor internal maupun eksternal yang menjadi pendukung maupun penghambat dari berjalannya pelaksanaan pembelajaran. Faktor internal merupakan faktor yang berasal dari seseorang sendiri dan dapat mempengaruhi terhadap belajarnya.Sedangkan faktor eksternal adalah faktor yang berasal dari luar pribadi peserta didik. Faktor eksternal mencakup ranah yang sangat luas sehingga kondisi yang memicu juga memiliki ragam yang sangat banyak. Adapun hal tersebut dapat menjadi faktor penunjang maupun penghambat dalam pelaksanaan program pembelajaran.

Faktor pendukung yang menunjang keberhasilan pembelajaran Al-Qur'an dengan metode tilawati di SDIT Bintang diantaranya adalah:

1) Sarana dan prasarana yang memadai. Sarana dan prasarana di SDIT Bintang yang memadai dalam menunjang keberhasilan dalam proses pembelajaran

2) Komunikasi yang baik dengan wali murid. Jalinan komunikasi yang baik dan keterbukaan akan permasalahan yang ada di akan menghindarkan dari kesalah pahaman.

3) Kerjasama yang baik antar guru tilawati. Mengadakan muroja'ah (mengulang) atau belajar bareng dan berdiskusi yaitu mungkin ada bacaan tertentu yang belum dipahami oleh sang guru dan pecahkan bersama 
Faktor penghambat dalam pembelajaran $\mathrm{Al}-\mathrm{Qur}$ 'an dengan metode tilawati di SDIT Bintang diantaranya:

1) Cuaca. Keadaan iklim yang tidak menentu dapat berpengaruh pada siswa untuk tidak masuk kelas. Selain itu perlunya pengawasan dan kontrol terhadap peserta didik agar tidak bermain hujan-hujanan yang nantinya dapat menyebabkan sakit.

2) Kemampuan anak yang berbedabeda. Kemampuan setiap anak secara umumnya memang berbeda-beda, termasuk juga di SDIT Bintang. Latar belakang keluarga anak yang berbeda, keluarga sebagai orang yang paling dekat dengan anak jadi paling berpengaruh terhadap perkembangan anak.

4. Hasil dari Penerapan Pembelajaran Al-Qur'an dengan Menggunakan Metode Tilawati di SDIT Bintang

Hasil belajar merupakan puncak dari sebuah proses belajar. Pembelajaran dinyatakan berhasil apabila hasilnya memenuhi tujuan yang telah ditentukan sebelumnya. Dari hasil observasi peneliti pembelajaran Al-Qur'an di SDIT Bintang evaluasi atau munaqosyah pembelajaran tilawati dilakukan dari jilid satu sampai jilid enam.

Aspek yang dinilai yaitu Tajwid, Fasohah, suara dan lagu. Pencapaian atau hasil munaqosyah menunjukkan hasil yang bagus. Pencapaian hasil pembelajaran yang bagus tersebut tentunya tak lepas dari minat dan kemampuan siswa yang meningkat daripada sebelumnya. Tidak hanya itu saja tetapi keutungan lain yang didapati adalah kepercayaan diri anak lebih jauh meningkat daripada sebelumnya.

Berdasarkan wawancara diatas tentang hasil dari penerapan metode tilawati di SDIT Bintang peneliti menyimpulkan bahwa metode tilawati sangat baik sehingga anak dapat kesenangan tersendiri dalam proses pembelajaran dan meningkat jauh lebih baik serta mengutamakan pada peningkatan kemampuan siswa dalam membaca Al-Qur'an hal tersebut tampak dari hasil penilaian atau munaqosyah yang telah dilaksanakan. Selain itu pembelajaran dengan metode tilawati ini juga berdampak pada meningkatnya kepercayaan diri para siswa.

\section{SIMPULAN}

Dari penelitian yang telah dilakukan oleh peneliti dengan mengangkat judul Efektivitas Metode Tilawati dalam Peningkatan Kemampuan Membaca $\mathrm{Al}^{-}$ Qur'an siswa di SDIT Bintang Serpong Utara Tangerang Selatan, dapat disimpulkan beberapa hal diantaranya yaitu:

1. Kemampuan membaca Al-Qur'an siswa di SDIT Bintang Serpong Utara Tangerang Selatan. Kemampuan membaca Al-Qur'an yang baik dan benar adalah benar bacaannya, baik dan lancar dalam melafadzkannya, tepat dan sesuai dari segi makhraj dan ilmu tajwidnya. Dan kemampuan membaca Al-Qur'an sebelum masuk ke SDIT Bintang relatif sedang, ada yang sudah bisa membaca ada juga yang belum bisa membaca $\mathrm{Al}^{-}$ Qur'an.

2. Penerapan pembelajaran Al-Qur'an dengan Metode Tilawati di SDIT Bintang. Diterapkannya metode tilawati sebagai metode dalam pembelajaran membacaAl-Qur'an merupakan salah satu upaya untuk meningkatkan kualitas pendidikan agama Islam. SDIT Bintang Serpong utara Tangerang selatan adalah salah satu dari sekian banyak lembaga pendidikan Islam yang menerapkan metode tilawati dalam pembelajaran membaca Al-Qur'an menggunakan metode tilawati.

3. Faktor Pendukung dan Faktor Penghambat dari Penerapan Pembelajaran Al-Qur'an dengan Menggunakan Metode Tilawati di SDIT Bintang . Faktor pendukung yang menunjang keberhasilan pembelajaran al-Qur'an dengan metode tilawati di SDIT Bintang diantaranya yaitu Sarana dan prasarana di SDIT Bintang yang memadai dalam menunjang 
Vol. 2 No. 1, Januari 2021

keberhasilan dalam proses pembelajaran, Komunikasi yang baik dengan wali murid dan Kerjasama yang baik antar guru tilawati . Sedangkan faktor penghambat dalam pembelajaran $\mathrm{Al}^{-}$ Qur'an dengan metode tilawati di SDIT Bintang diantaranya yaitu Cuaca dan kemampuan anak yang berbeda-beda dalam membaca.

4. Hasil dari Penerapan Pembelajaran Al-Qur'an dengan Menggunakan Metode Tilawati di SDIT Bintang. Metode tilawati sangat baik sehingga anak dapat kesenangan tersendiri dalam proses pembelajaran dan meningkat jauh lebih baik serta mengutamakan pada peningkatan kemampuan siswa dalam membaca Al-Qur'an hal tersebut tampak dari hasil penilaian atau munaqosyah yang telah dilaksanakan. Selain itu pembelajaran dengan metode tilawati ini juga berdampak pada meningkatnya kepercayaan diri para siswa.

\section{DAFTAR PUSTAKA}

Muhammad ibn Muhammad Abu Syahbah, Al-Madkhal li Dirasatil Qur'an alKarim. Maktabatus Sunnah, tt

Ahmad Syarifuddin. 2004. Mendidik Anak Membaca, Menulis, dan Mencintai Al- Qur'an. Gema Ismani. Jakarta.

Darmadi. 2017. "Membaca Yuk, Strategi Menumbuhkan Minat Baca Pada Anak Sejak Usia Dini". Gupedia:"Pengembangan Model dan Metode Pembelajaran dalam Dinamika Belajar Siswa",Cet, Pertama: CV. Budi Utama, Sleman

Ahmad Warson Munawwir, Al Munawwir. 2001. Kamus Bahasa Arab-Indonesia Yogyakarta: Unit Pengadaan Buku-buku Ilmiah Keagamaan Pondok Pesantren "Al Munawwir" Krapyak Yogyakarta.

M. Quraish Syihab. 1998. Wawasan Tafsir Al-qur'an Maudhu'I atas
Berbagai

Persoalan Umat:

Mizan, Bandung.

Ahmad Munjin Nasih. 2009. Metode dan Teknik Pembelajaran Pendidikan Agama Islam. PT Refika Aditama, Bandung.

Muhammad Ali Bakri. 2017. Metode Langsung (Direct Method) dalam Pengajaran Bahasa Arab, AlMarji. dalam Jurnal Pendidikan Bahasa Arab. Vol. 1. No. 1.

M. Misbahul Munir. 1997. Pedoman Lagu-lagu Tilawatil Qur'an dilengkapi Tajwid dan Qasidah, cet.3, Apollo, Surabaya.

Ali Muaffa, dkk. 2008. Strategi Pembelajaran Al-Qur'an Metode Tilawati, Pesantren AlQur'an Nurul Falah, Surabaya.

Slavin R.E 2000., Educational Psychologi: Theory and Practic, sixth Edition. Boston; Allyn.

Abdurrahim Hasan, dkk. 2010. Strategi Pembelajaran Al-Qur'an Metode Tilawati, Pesanteren AlQur'an Nurul Fallah PTT VB, Surabaya.

Anshori. 2014. Ulumul Qur'an kaidahkaidah memahami firman Tuhan, PT Raja Grafindo Persada, Jakarta.

Al Abror Muhammad. 2011. Belajar Ilmu Tajwid Mudah dan Praktis dengan Skema dan Terstruktur, Media Pustaka Ainun,Jakarta Barat.

Wahyudi Moh. 2008. Ilmu Tajwid Plus, Halim jaya, Surabaya.

Sugiyono. 2017. Metode Penelitian Pendidikan. Alfabeta, Bandung.

Mardalis. 2003. Metode Penelitian, Cet. VI, Bumi Aksara, Jakarta.

Helaludin Hengki Wijaya. 2019. Analisis Data Kualitatif, Sebuah Tinjauan Teori dan Praktik. Sekolah Tinggi Theologi Jaffary.

J.R.Racoo. 2010. Metode Penelitian Kualitatif, Jenis, Karakteristik, dan Keunggulannya.

Grasindo, Jakarta.

Lexy J. Moleong. 2001, Metodologi Penelitian Kualitatif, PT. Remaja Rosdakarya, Bandung.

Ramayulis. 2005. Metodologi Pendidikan Agama Islam, Kalam Mulia, Jakarta. 
M. Misbahul Munir. 1997. Pedoman
Lagu-lagu Tilawatil Qur'an Vol. 2 No. 1, Januari 2021 dilengkapi Tajwid dan Qasidah, cet.3. Apollo, Surabaya.

Ali Muaffa, dkk. 2008. Strategi Pembelajaran Al-Qur'an Metode Tilawati, Pesantren Al-Qur'an Nurul Falah, Surabaya.

Abdurrahim Hasan. 2010. dkk, Strategi Pembelajaran Al-Qur'an Metode Tilawati, Pesanteren $\mathrm{Al}^{-}$ Qur'an Nurul Fallah PTT VB, Surabaya. 